\title{
JUDICIAL DISCRETION IN THE DETERMINATION OF POST-DIVORCE CHILD SUPPORT: A BRIEF OVERVIEW OF THE APPLICATION OF THE SOUTH AFRICAN MAINTENANCE ACT 99 OF 1998 AS COMPARED TO THE CANADIAN FEDERAL CHILD SUPPORT GUIDELINES OF 1997
}

\section{Introduction}

There are various models for determining and allocating child support obligations post-divorce and many different principles upon which such a policy can be based (Wikeley Child Support. Law and Policy (2006) 3). In most legal systems the parents retain the duty to support their needy children after divorce as it is primarily their obligation to ensure the adequate financial welfare of their children (Skinner and Davidson "Recent Trends in Child Maintenance Schemes in 14 Countries" April 2009 International Journal of Law, Policy and the Family 2526 ). This principle is applicable in both the South African and Canadian legal systems.

In South Africa, in terms of both the common law and legislation, both parents must maintain their children "according to their respective means" (s 15 of the Maintenance Act 99 of 1998; and Bursey v Bursey 19993 SA 33 (SCA) 36c-d). The awarding of a specific amount of maintenance is, however, a complex process calculated by the courts on a case-by-case basis mainly by considering two issues: the needs of the children and the parents' ability to maintain their children within the circumstances and means of each of the parents (Buch $v$ Buch 19673 SA 83 (T) 88; and Herfst $v$ Herfst 19644 SA 127 (W) 132).

Although both aspects are important in a maintenance enquiry, the focus of this note is on the interpretation of the calculation of the contribution of each of the parents, especially the non-custodial parent. The interpretation of the concept "means" obviously has important consequences for the parties: the broader the interpretation of the "means" of a parent, the higher the proportion of the contribution of that parent would be towards the support of the children. This is especially important in South Africa where a substantial proportion of those who are obligated to pay maintenance is impecunious ( $S$ v Koopman 19981 SACR 621 (C) 624b-c).

The Canadian law rested on similar principles until 1997 when the federal government promulgated the Federal Child Support Guidelines (Can. Reg. 97-175) as an amendment to the Divorce Act (R.S.C. 1985 (2 ${ }^{\text {nd }}$ Supp.) c.3). 
The impact of these Guidelines on the calculation of the parental share of post-divorce child support has been far-reaching.

The aim of this note is firstly to examine the meaning of the term "means" within the South African legal system as set out in the common law, the various statutes and as these have been interpreted by the majority of courts over the past century. The second aim is to give a brief overview of the Canadian Guidelines and to compare their current system with the South African scenario. The rationale for choosing this jurisdiction is (i) the fact that in both jurisdictions the courts have the ultimate say over the amount of support paid (Skinner and Davidson April 2009 International Journal of Law, Policy and the Family 35); and (ii) as the Canadian position before their 1997 amendments was similar to the current South Africa system, it was envisaged that by exploring their reasons for change and evaluating their current system, some useful insights might be gained in solving some problems experienced in the South African maintenance system. The note will conclude with some suggestions for reform in South Africa in light of the Canadian experience.

\section{South African law}

\section{Common law}

"The Roman-Dutch authorities are quite clear that the burden of supporting the children, whether before or after a divorce, is a burden common to the two spouses, the only qualification being that it is distributable between them according to their means" (Farrell v Hankey 1921 TPD $590596 \mathrm{H}$ ).

In common law the obligation on the parents was to maintain their children "in proportion to the resources which lie to the hand of each spouse" (Voet 2536 [Van der Linden The Selective Voet Being the Commentary on the Pandects Paris Edition of 1829 by Johannes Voef] translated by Percival Gane Vol IV (1956) 363; see also Nathan The Common Law of South Africa Vol I Persons and Property 2ed (1913) par 140; and the Supreme Court of Appeal case of Union Government $v$ Warneke 1911 AD 166). What qualified as resources was not defined.

The first statute dealing specifically with the maintenance of children was the then Colony of Natal's Deserted Wives and Children Protection Act 10 of 1896. This Act set out to criminally punish a person for wilfully neglecting to support his family if he was able to do so "by work or other means" (s 1). This provision prima facie included both income and other assets. The other three provincial statutes, the Deserted Wives and Children Protection Act 7 of 1895 (Cape); the Deserted Wives and Children Protection Ordinance 51 of 1903 (Orange Free State) and the Deserted Wives and Children Protection Ordinance 44 of 1903 (Transvaal), were identical on this point. All these statutes were repealed by the Maintenance Act 23 of 1963.

The wording in the (now repealed) Maintenance Act 23 of 1963, however, differed from the provincial statutes it replaced. It stated in section 4(1): 
Whenever a complaint on oath is made to a maintenance officer to the effect that -

(a) any person legally liable to maintain any other person fails to maintain such other person; or

(b) sufficient cause exists for the substitution or discharge of a maintenance order,

the maintenance officer may, after investigating such complaint, institute an enquiry ... for the purpose of enquiring into the provision of maintenance in respect of the person concerned, and may for that purpose cause any person, including any person legally liable to maintain any other person, to be summoned to appear before such court and give evidence or produce any book, document or statement, including, in the case of a person so liable, a statement giving full particulars of his earnings signed by his employer (author's emphasis).

Although the section specifically refers to evidence provided in relation to the earnings of the liable person, the word "including" clearly denotes that a person's earnings was not the only evidence that could be required. By implication, evidence could be led relating to other resources and assets (see the cases between 1963 and 1998 infra under 4). More problematic was section $7 \mathrm{~A}(1)$ of the same Act that read as follows:

"A magistrate may ... require the appearance ..., for interrogation ..., of any person who is likely to give material or relevant information as to the identification, location or earnings of any person who is legally liable to maintain any other person, or who is allegedly so liable ..."

In this section, the material that could be requested from a third party was prima facie limited to the earnings of the liable person and not on all aspects relating to his or her "means". This made the obtaining of evidence from third parties problematic. Nonetheless, it is submitted that although this statute dealt specifically with the provision of evidence relating to earnings, it did not amend the common law duty on both parents to support their children according to their respective "means". This conclusion is evident from the word "including" in section 4(1).

\section{Maintenance Act 99 of 1998}

The Maintenance Act 99 of 1998 avoided this controversy and specifically confirmed the common law position that there is a duty on parents to support their children according to their respective "means" ( $\mathrm{s} 15$; and see also $\mathrm{s}$ $40(3)(a))$. This principle has been confirmed by various courts, including the Supreme Court of Appeal (inter alia Mentz v Simpson 19904 SA 455 (A) 458A-B; and $B v B$ [1999] 2 All SA 289 (A) 291); and the Constitutional Court (by implication, in Bannatyne $v$ Bannatyne (Commission for Gender Equity, as Amicus Curiae) 20032 SA 362 (CC)). With the principle confirmed, the question remains how the concept of "means" should be interpreted.

Recently, in the Pietermaritzburg maintenance court, it became apparent that the focus of a maintenance officer, when determining the "means" of a parent, was solely on the income of that parent, seemingly to the exclusion of other assets and property of the person. This will be shown to be incorrect, but unfortunately this error is not unique as the court in Farrell $v$ 
Hankey (supra 596) also ignored some immovable assets (erven) of the maintenance debtor and focused only on his income when determining the payment of arrear maintenance.

As the term "means" is not and has never been defined by the legislation, its meaning should be sought elsewhere. According to the Webster Dictionary (http://www.websters-online-dictionary.org/definition/means) "means" connotes the available resources, synonyms being inter alia "wealth, assets, belongings, resources, what one is worth". It is submitted that this wider definition is in line with Voet's reference to "resources" as well as the interpretation in several cases: Van der Harst $v$ Viljoen (1977 1 SA 795 (C) 798A, using "resources" as a synonym for "means"); Lamb v Sack (1974 2 SA 670 T 673F-G, included "financial resources" under the term "means"); Price v Price (1948 1 SA 518 (SR) 521, included in "means of support" "some available property or right by the use of which support can be procured"); and Amaneeammah $v$ Naidoo (1948 3 SA 712 (D) 719, specifying that income is not the sole guide of "means").

In an attempt to be more specific and to paint a clearer picture of the term "means", an overview of the reported judgments shows that the following aspects have been included within the term "means" by the courts:

Firstly, income, including employment income, income derived from trusts, share dividends, interest on capital donations as well as rent income $(A \vee M$ 1930 WLD 292 293; 295; Buch v Buch supra 88; Lamb v Sack supra 673FG; Stark NO v Fisher NO 1935 SWA 53 58; and Schafer Family Law Service C28). How income is spent is also considered by the court. In Harwood $v$ Harwood (1976 4 SA 586 (C) 587) the court took into consideration that the bond repayment included a percentage of capital repayment that could be reallocated towards the maintenance obligation.

Secondly, capital in the form of savings and assets, including immovable property (Van der Harst $v$ Viljoen supra 798B-E; Spiro The Law of Parent and Child 4ed (1985) 393; 398; Van Zyl Handbook of the South African Law of Maintenance (2000) 8; Slabbert v Harmse (1923) CPD 187 190; Price $v$ Price supra 521; Boulle v Boulle 19661 SA 446 (D) 448; and Van Wyk v Van Wyk 19593 SA 223 (T)). A few findings of the courts should be highlighted. In Pillay $v R(19501 \mathrm{PH} \mathrm{H} 24(\mathrm{~N}))$ the court found that an obligation to maintain a child was not an obligation which could only be discharged out of income. If necessary, a person must use his capital for that purpose. The judge in Davis v Davis (1945 2 PH B36 (WLD)) took into account the fact that the defendant was a man of considerable means, possessing immovable property and a clothing factory. Although there was no direct evidence as to his income, the court ordered him to pay maintenance. In instances where property is regarded as too much of a luxury under the circumstances, the court can order it to be sold to defray any maintenance obligation (Kroon $v$ Kroon 19864616 (E) 624e).

The courts have granted orders to secure future maintenance for a child directly from lump sum investments or other assets: Soller $v$ Maintenance Magistrate, Wynberg (2006 2 SA 66 (C) [annuity]); Burger v Burger (2006 4 
SA 414 (D) [proceeds from the sale of immovable property]); Magewu $v$ Zozo (2004 4 SA 578 (C) [pension fund benefits]); and Mngadi $v$ Beacon Sweets \& Chocolates Provident Fund (2004 5 SA 388 (D) [pension benefits]). Surely if these capital assets can be used for securing future maintenance, they can also be used for current maintenance needs!

However, not all assets are regarded as "means" because certain restrictions apply. Where the liable person is obviously not wealthy, the court could exclude limited household goods in determining the "means" of a person (Woodhead $v$ Woodhead 19553 SA 138 (SR) 142). In Lindsay $v$ Otten ([2006] JOL $17489(\mathrm{~N})$ par 24) the court did not require a parent to use capital in the support of children where the consequence would be to deprive that parent of the means to support herself and leave her destitute. Moreover, in Kroon $v$ Kroon (supra 624e) the court held that if a property can be sold and some of the proceeds used to produce income, it represents "means". However, the court was of the opinion that although the house was potentially "means", the car and furniture could not be regarded as "means" because they were considered to be capital assets needed for her own use and that of the children, that is, for the use and benefit of the family as a whole.

Thirdly, assets donated away (Wille Principles of South African Law 9ed (1991) 484), including donations to trusts (Buch $v$ Buch supra 84D-H). A person liable for maintenance cannot escape his burden by filtering assets to others, including separate legal entities.

Lastly, assets of a new marriage in community of property, or at least half thereof, may be considered as the means of the parent (Hartman $v$ Krogscheepers 19504 SA 421 (W)).

For the sake of completeness, it is useful to note that the courts also take other factors into consideration when determining the "means" of a person, specifically earning capacity, standard of living and the reason for the decline in financial situation.

With regard to earning capacity the court in Barlow $v$ Barlow (1920 OPD 73 77) described the term "means" as an elastic term referring to what a person has either in esse or in spe, actually or potentially. It is thus not only the actual resources of a person, but also his/her potential earning capacity that should be taken into consideration by the courts. In this regard, parents should realise the full potential of their earning capacity and not act to the detriment of their children (Lamb v Sack supra 674A-B; Van Zyl 8; and Mgumane $v$ Setemane 19982 SA 247 (Tk) 252B-E):

"An inability to pay maintenance or to pay the full amount required for maintenance must be real and not apparent. A parent cannot be allowed not to realise the full potential of his/her earning capacity to the detriment of his/her children who are in need of maintenance. In a given case the facts may amply demonstrate that a parent can earn more than he/she is actually earning and that it would be a matter of relative ease for him/her to so adjust his/her position as to be able to earn a higher income. In such a situation the courts would be failing in their duty if they were to accept a mere ipse dixit that the parent is unable to pay maintenance or to pay maintenance to the extent of the children's needs" (Mgumane v Setemane supra 252B-E). 
However, in Tate $v$ Jurado (1976 4 SA 238 (W) 242) the court was loathe to oblige the liable person to follow that path in a field which was not to his liking - even though it could ensure him the highest income. The court ordered him to pay a $55 \%$ contribution towards the needs of the child - a percentage the court indicated obiter that it would reconsider should his income increase. It is submitted that this case is not in line with the other judgments on this point and should not be followed.

A parent may also not escape the duty to maintain by resigning from work and embarking on full time university studies or by living in a manner which unduly interferes with the needs of a child (Martins $v$ Martins 19592 PH B19 (O); and Spiro 393). In Martins the father embarked on a five-year architectural degree course. The court took into account his ability to work and earn a salary and found that his duty was first to make provision for the support of his child before embarking on his studies - however noble his long term intentions might be. The court likewise applied the principle to the mother of the child who was a qualified nurse. Similarly, the court in Herfst $v$ Herfst (supra 130) demanded that the parent return to work to enable her to contribute towards the maintenance of the child. A parent cannot be allowed not to realise the full potential of his/her earning capacity to the detriment of his/her children who are in need of maintenance (Mgumane $v$ Setemane supra ...).

Regarding standard of living, a parent cannot escape the duty to maintain by keeping a standard of living that unduly interferes with the needs of the child. Where the liable parent contracted a second marriage he/she must adjust his/her standard of living so that the children would not be prejudiced (Scott v Scott 1946 WLD 399 403-4; Spiro 393; and Herfst v Herfst supra 132).

In an application for a reduction of maintenance as a result of deterioration in the financial position of the liable parent, the court will establish whether the financial decline is due to circumstances beyond the liable parent's control. If he/she was the cause of the decline, the court is less sympathetic (Van Heerden Boberg's Law of Persons and the Family 2ed (1999) 242; see also Hancock v Hancock 19572 SA 500 (C); and Mentz $v$ Simpson supra). Any amendment to an order must, however, be made via court order where the parties cannot agree (Power $v$ Power [2009] JOL 23848 (KZD); and s 8 of the Divorce Act 70 of 1979).

In conclusion it is clear that judicial discretion plays a pivotal role in the determination of the means of a party and therefore the amount of maintenance to be paid. The factors to be considered are complex and the courts are not always consistent in their interpretation of the various principles as there are no fixed guidelines or a starting point in how to calculate the due amount. This inconsistency makes it difficult for practitioners and clients to predict the likely outcome of an application.

Added to the above problem, is a mix of already documented problems with the maintenance system: cumbersome forms; the logistical and evidentiary burden on the claimant who often regards the legal process as 
complicated, user-unfriendly and not protective of the needs of the claimant; attempts to "hide" assets, bullying, coercion and other behaviours designed to minimize ongoing financial obligations; and the overburdening, excessive workload and chaos in some of the maintenance courts (Mamashela "Some Hurdles in the Implementation of the Maintenance Act 99 of 1988" 2006 Obiter 590; "The Implementation of the Maintenance Act 99 of 1998: Two NGOs Throw Down the Gauntlet - A Model for the Country?" 2005 South African Journal on Human Rights 490; Mthimunye "Staying in Line with the Intentions of the Legislature" in Budlender and Moyo (eds) What About the Children? The Silent Voices in Maintenance (2004) Tshwaranang Legal Advocacy Centre 119; Singh, Naidoo and Mokolobate "Coming to Court for Child Support - The Policy, the Practice and Reality. A Case Study of Black Women in the Maintenance System at the Johannesburg Family Court [2002-2004]" 2004 Acta Criminologica 143; and Kelly "Onderhoud - Eers Weeskind, Nou Stiefkind" 2000 XXXXI(1) Codicillus 55). All these factors result in thoughts that rigid guidelines prima facie sound tempting as they could assist parties, practitioners and presiding officers in the standardisation of orders applicable in similar circumstances. One can rightly ask whether the Maintenance Act has met its main objectives as set out in its preamble, namely to simplify maintenance procedures and to make them speedier and cheaper and the enforcement machinery more effective. Or should other avenues be sought for relief?

\section{Canadian Child Support Guidelines}

The child support system in Canada in 1997 changed from a "needs-based" approach (similar to the current South African system) to a "means-based" approach with the adoption of the Federal Child Support Guidelines (Can. Reg. 97-175) of 1997 (Robson "Wrapped in the Flag of the Child: Divorced Parents' Perceptions of and Experiences with the Federal Child Support Guidelines" 2008 Canadian Journal of Family Law 283 296). The basic Canadian legal principle is that both parents have joint financial responsibility to support their children, although it means different things for the custodian and non-custodian parents: the non-custodian has to pay maintenance and the custodian has to supply the home (Robson 2008 Canadian Journal of Family Law 311).

The Guidelines were aimed at establishing a child-focused, fair, more objective standard of support for children to ensure that they continue to benefit from the financial means of both spouses after separation (s 1(a)(b)); improving adequacy of maintenance amounts ordered and thus increasing the predictability of awards and therefore encouraging settlement agreements (s 1(c)); and, improving consistent treatment of spouses and children in similar circumstances (s 1(d)). In general the amendments focused on rectifying the inequity created by the previous system mainly through the reduction of judicial discretion (Robson 2008 Canadian Journal of Family Law 284; and Skinner and Davidson April 2009 International Journal of Law, Policy and the Family 27-28). Since the introduction of these 
Federal Guidelines, various Provincial Child Support Guidelines have also been promulgated.

The crux of the current Canadian system is the basis used for the calculation of the maintenance duty of the non-custodial parent. The Guidelines are based on the income or net earnings of the non-custodial parent after the calculation of various taxes (Schedule I note 6). The Guidelines differ from province to province as a result of differences in income tax rates (Schedule I as read with Note 4). The formula sets support amounts to reflect average expenditures on children by a spouse with a particular number of children and level of income (Schedule I note 6). The amounts are based on economic studies of average spending on children in families at different income levels in Canada and are calculated using a mathematical formula generated by computer programme (Schedule I Note 5). For example, a non-custodian parent with two children in British Columbia with an annual income of $\$ 33760$ would have to pay $\$ 525.56$ in support monthly (Schedule I Note 3).

The calculation of annual income forms the basis of the calculation and is determined using sources of income set out in Schedule III of the Guidelines (s 16). The court retains its discretion, however, and may adjust the figures to make provision for a variety of possibilities such as patterns of income, fluctuations, non-recurring income and losses (s 17); and pre-tax income of any corporation the person is a shareholder, director or officer of (s 18; $T$. (R.) v. D. (D.) 2009 CarswellBC 1223). The court may in addition impute certain amounts of income in certain circumstances, including where the person is intentionally under-employed or unemployed (s 19(1)(a); and Homsi v Zaya 2009 CarswellOnt 2068); where it appears that income has been diverted that could affect the determination of child support ( $\mathrm{s}$ $19(1)(d))$; where the person's property is not reasonably utilized to generate income (s 19(1)(e)); or where the person is a beneficiary under a trust and is or will be in receipt of income or benefits from the trust (s 19(1)(i)). The Guidelines obligate parties to provide information on an ongoing basis (s 21 as read with s 25). Schedule III provides for certain adjustments to the annual income for inter alia special or extraordinary expenses (art 3.1), social assistance (art 4), capital gains and losses (art 6), and business investment losses (art 7). Special provision is made for the determination of net self-employment income (art 9).

There is a presumption in favour of the Guidelines figures and these figures can only be increased or decreased by the court if the party seeking deviation rebuts the presumption of appropriateness (Francis v Baker [1999] 3 S.C.R. 250). Other factors may be considered: firstly, special or extraordinary expenses (s 7; Hanson v Hanson 1998 CarswellNat 2443); secondly, split custody (s 8; Wall $v$ Wall 2009 CarswellAlta 716); thirdly, shared custody (s 9; Contino v Leonelli-Contino ([2005] 3 S.C.R. 217; and see also the discussion of the court a quo decision in Colman "Contino $v$ Leonelli-Contino - A Critical Analysis of the Ontario Court of Appeal Interpretation of Section 9 of the Child Support Guidelines" 2004 Canadian Journal of Family Law 291); and fourthly, possible undue hardship that may 
include circumstances of unusually high expenses relating to exercising access to the child (s 10(2)(b)); other child support obligations (s 10(2)(d)) and standard of living (s 10(3)). Research has shown that the courts are conservative in the application of the Guidelines and that despite the judicial discretion to vary the table amounts upwards, such orders are rarely made (Robson 2008 Canadian Journal of Family Law 314).

For purposes of completeness it should be mentioned that the issue of retroactivity of the awards was controversial, for instance, should a custodian be able to claim from the non-custodian parent that which, in hindsight, should have been paid before. In the case of $S$. (D.B) $\vee$ G. (S.R) and three other matters (2006 SCC 37), the Supreme Court of Canada found that the court must balance the interests of certainty and predictability with the need for fairness and flexibility taking into account the reason for the recipient's delay in seeking child support, the conduct of the liable parent, the past and present circumstances of the child and the hardship imposed by a retroactive award. The date of retroactivity would be the date of effective notice by the recipient parent that child support should be increased. There is, however, not an automatic disclosure obligation every time the income increases. It is the duty of both parents to ensure that the child receives adequate support. The majority judgment indicated that it would be inappropriate to make such an order to a date more than three years before formal notice was given. Although this is a complicated approach, it has been described as balanced and flexible (Annotation to $S$. (D.B) v G. (S.R). See also Mann v Mann 2009 CarswellBC 1065). A further discussion of this issue falls outside the scope of this note.

It is noteworthy that the resources of the parent with care (custody) are not taken into account when calculating the amount of the child maintenance, except for in Quebec (Maisonneuve "Child Support Under the Federal and Quebec Guidelines: A Step Forward or Behind?" 1999 Canadian Journal of Family Law 284 311; and Skinner and Davidson April 2009 International Journal of Law, Policy and the Family 38). The federal argument for not taking these resources into account was based on the presumption that the custodian parent necessarily contributes to the maintenance of the child in proportion to his or her income whilst the Quebec model is based on the ability to pay of both parents on a pro rata basis according to their resources (Maisonneuve 1999 Canadian Journal of Family Law 311).

The tables are applicable up to an annual income of $\$ 150000$. Where the non-resident spouse has an income over $\$ 150000$, the court may make an order for the maintenance that it considers appropriate, having regard to the condition, means, needs and other circumstances of the children and the financial ability of each spouse to contribute towards the support of the children (s 4(b)(ii)). There is in these instances no cap or upper limit on childsupport awards (Francis $v$ Baker [1999] 3 S.C.R. 250; and James $v$ James 2009 CarswellBC 1490 par 12).

One of the consequences of these Guidelines is that the vast majority of cases are settled outside the court as there is certainty about the amount 
due (Annotation to $S$. (D.B) $v$ G. $(S . R)$ ). This saves claimants the emotional and financial costs of protracted and difficult negotiations and litigation and closes the gap between those individuals who are theoretically entitled to support and those who are actually awarded their due (Gordon "Spousal Support Guidelines and the American Experience: Moving Beyond Discretion" (2002) Canadian Journal of Family Law 247 257-260).

Except for Newfoundland, the provinces in Canada do not have an automatic annual re-calculation process to update support payments even though the paying parent's income may have increased. An adjustment can only be affected by a new court order (Bonnet "Recalculating D.B.S.: Envisioning a Child Support Recalculations Scheme for Ontario" 2007 Canadian Journal of Family Law 115 116). Although the amount should theoretically be linked to the current income of the parent, after a few years the basis for calculation becomes outdated, inadequate and no longer linked to the current income (Robson 2008 Canadian Journal of Family Law 310). The onus is on the receiving parent to approach the courts, a burdensome and costly process (Bonnet 2007 Canadian Journal of Family Law 116). Bonnet argues that an administrative process of re-calculation should be implemented that could reconcile public policy considerations and society's interest in a more efficient process. He argues that the shifting of the burden of determining child support payments from the private to the public sphere would create an appropriate balance between efficiency and the discretion of the courts without the obligation on the custodian parent to seek an increase each time the income of the other parent increases (Bonnet 2007 Canadian Journal of Family Law 156). That is of course presuming that the information is made available. It has been reported that the Federal government is in the process of enacting automatic adjustment for child support agreements with the hope that an administrative mechanism in each province would annually calculate child support (Annotation to $S$. (D.B) $v$ G. $(S . R)$ ).

The Canadian system is not without criticism and clearly still developing to adjust to the needs of society. Robson (2007 Canadian Journal of Family Law) notes that although one of the issues that was regarded as unfair prior to the introduction of the Guidelines was the fact that the custodian parent had to take the initiative and bear the cost for claiming child support, it has not changed (299). Furthermore, the system remains combative and adversarial in instances where there is no settlement (302) and parties still felt that they have "lost control" once their case entered the system (305). Their perceptions of powerlessness have not diminished in the new system (313).

\section{Conclusion}

The problems with the maintenance system in South Africa are well documented. This note attempts to add an additional dimension to the already recognised frustrations experienced by practitioners and claimants alike, namely the wide and unpredictable discretion of the court in the making of maintenance awards, especially where the party is not a mere salary earner. The Canadian system shows that there is another way of 
calculation that might be worth considering. There are a few elements within their system that might have merit in South Africa: the fact that the guidelines are a starting point and only where there is a dispute does the matter have to go to court. The judicial discretion is not taken away, although there would be some basis for the calculation of the maintenance amount. The outcome would in most cases be more predictable and certain and it could potentially address the over-burdening in the courts. Most cases would be settled reducing the emotional trauma that the maintenance courts inevitably seem to cause. The burden on the custodian parent to go to court and drive the claim as well as the evidentiary burden would be minimised. Noteworthy is the fact that the system also makes provision for individual circumstances to be taken into account as well as where there is an attempt to avoid making payments. Moreover, the issue of an annual adaptation of existing maintenance awards should be considered as it would alleviate the necessity to return to court for an increase when required - the reality of inflation and annual increases for most salary earners could be accounted for upfront. It is not argued that the system would magically solve all the problems and would no doubt create new obstacles.

It is submitted that the time has come for the South African Law Reform Commission and the Department of Justice to research the problems within the maintenance system as a whole comprehensively and to look afresh at other ideas and solutions used in other legal systems. The Canadian system is but one possibility. One can only agree with Mokgoro $J$ in her Constitutional Court judgment that

"(t)he hardships experienced by maintenance complainants need to be addressed and the proper implementation of the provisions of the Act is a matter that calls for the urgent attention of the Department of Justice" (Bannatyne v Bannatyne (Commission for Gender Equity, as Amicus Curiae) supra par 32 ).

Marita Carnelley 